\title{
Sporobolomyces bannaensis, a novel ballistoconidium-forming yeast species in the Sporidiobolus lineage
}

\author{
Jian-Hua Zhao, Feng-Yan Bai, Qi-Ming Wang and Jian-Hua Jia \\ Systematic Mycology and Lichenology Laboratory, Institute of Microbiology, Chinese Academy \\ of Sciences, Beijing 100080, China
}

Correspondence

Feng-Yan Bai

baify@sun.im.ac.cn

\begin{abstract}
Among ballistoconidium-forming yeast strains isolated from various plant leaves collected in Banna, Yunnan Province, China, five strains that formed pink-coloured colonies and asymmetric ballistoconidia were classified in a single group and assigned to the genus Sporobolomyces by conventional and chemotaxonomic studies. Analyses of the internal transcribed spacer region and 26S rDNA D1/D2 domain sequences indicated that these strains represent a novel species with a close phylogenetic relationship to Sporobolomyces blumeae in the Sporidiobolus lineage, for which the name Sporobolomyces bannaensis sp. nov. is proposed (type strain $\mathrm{Y} 41^{\top}=$ AS $2.2285^{\top}=$ CBS $9204^{\top}$ ).
\end{abstract}

The high frequency with which novel ballistoconidiumforming yeast species have been discovered in the Kunming area of Yunnan Province, China (Bai et al., 2001a, b, 2002a, b, 2003), encouraged us to investigate basidiomycetous yeast diversity in other areas of Yunnan. In January 2001, approximately 130 strains were isolated from 16 plant leaf samples collected in Xishuang Banna, the tropical rain forest area of Yunnan, using the improved ballistoconidia fall method (Nakase \& Takashima, 1993). After morphological, physiological and biochemical characterization according to standard methods (Yarrow, 1998), five strains isolated from wilting leaves of Synsepalum dulcificum (Y01), Sterculia sp. (Y02), Arenga candata (Y11 and Y87) and Theobroma cacao $\left(\mathrm{Y} 41^{\mathrm{T}}\right.$ ) were classified in a single group because of their similar phenotypic characters. They formed pink-coloured colonies and asymmetric ballistoconidia. The major ubiquinone of the representative strain, $\mathrm{Y} 41^{\mathrm{T}}$, was $\mathrm{Q}-10$, determined using the method of Yamada \& Kondo (1973). Sexual structures were not observed in mating tests between the strains studied. Conventional taxonomic study suggested that this group of strains belongs to the genus Sporobolomyces as defined by Boekhout \& Nakase (1998). The carbon and nitrogen compound assimilation patterns of these strains were similar to those of taxa in the Sporobolomyces roseus complex.

Published online ahead of print on 23 May 2003 as DOI 10.1099/ ijs.0.02807-0.

Abbreviation: ITS, internal transcribed spacer.

The GenBank accession numbers for the 26S rDNA D1/D2 domain sequence of $Y 41^{\top}$ and the ITS sequences of $Y 41^{\top}$ and $Y 01$ are respectively AY274823, AY274824 and AY274825.

A phylogenetic tree based on ITS sequences is available as supplementary material in IJSEM Online.
Molecular phylogenetic analyses of the five strains were then performed using methods described previously (Bai et al., 2002b). The D1/D2 sequences of these strains were identical. Their internal transcribed spacer (ITS) sequences were either identical or differed in only one or two positions. The molecular data suggest that these strains are conspecific. In phylogenetic trees drawn from the D1/D2 and ITS sequences, the Banna strains clustered in the Johnsonii clade of the Sporidiobolus lineage (Scorzetti et al., 2002). In the D1/D2 tree, these strains formed a separate branch (Fig. 1), whereas, in the ITS tree, they clustered closely with Sporobolomyces blumeae (tree available as supplementary material in IJSEM Online).

Pairwise comparisons of sequences indicated that this group of Banna strains differed from S. blumeae by $17 \mathrm{nt}(\sim 3 \%)$ in the D1/D2 domain. They differed from other species in the same clade by more than $20 \mathrm{nt}$ in this domain. In the ITS region, the strains differed from S. blumeae by 27-28 nt $(\sim 8 \%)$ and from other closely related species by $\geqslant 43 \mathrm{nt}$. These results indicate that the five strains from Banna represent a novel Sporobolomyces species, for which the name Sporobolomyces bannaensis is proposed.

It is not easy to find clear phenotypic differences between $S$. bannaensis sp. nov. and $S$. roseus when compared with the standard description of the latter (Boekhout \& Nakase, 1998). Though molecular phylogenetic analysis showed that S. bannaensis sp. nov. is most closely related to S. blumeae of the species in the Johnsonii clade, the novel species differed from the latter in assimilation of inulin, ethanol, glycerol, $\mathrm{KNO}_{3}, \mathrm{NaNO}_{2}$, L-lysine and cadaverine when compared with the original description of S. blumeae (Takashima \& Nakase, 2000). 


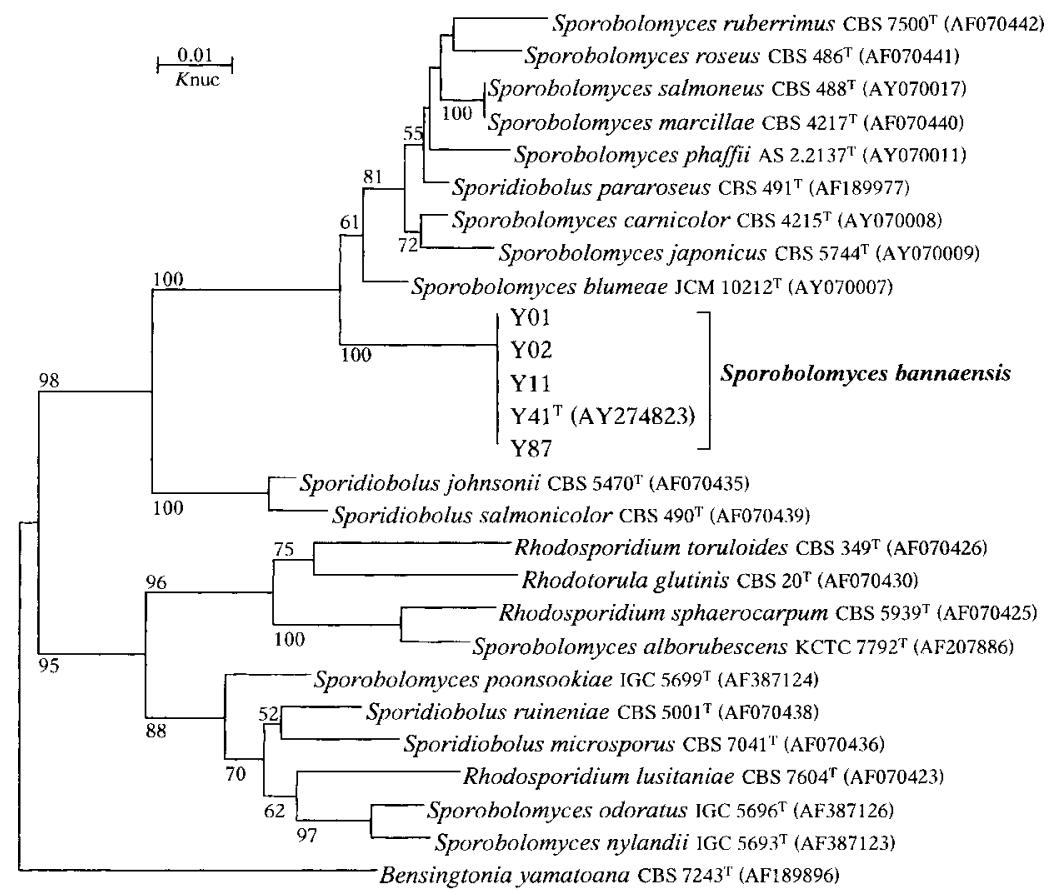

Fig. 1. Phylogenetic tree drawn from neighbour-joining analysis of 26S rDNA D1/ D2 domain sequences, depicting the relationship of Sporobolomyces bannaensis sp. nov. with closely related species. Bootstrap percentages over $50 \%$ from 1000 bootstrap replicates are shown.

\section{Latin diagnosis of Sporobolomyces bannaensis Bai et Zhao sp. nov.}

In liquido malti post dies 3 ad $20^{\circ} \mathrm{C}$, cellulae vegetativae, ovoideae, ellipsoideae vel elongatae, $2 \cdot 5-5 \cdot 0 \times 5 \cdot 0-10 \cdot 0 \mu \mathrm{m}$, singulae aut binae. Post unum mensem ad $20^{\circ} \mathrm{C}$, annulus, pelliculum et sedimentum formantur. In agaro malti post unum mensem ad $20^{\circ} \mathrm{C}$, cultura rosea, glabra, butyracea vel viscida, margine glabra. In agaro farinae zeae pseudomycelium non formantur. Ballistosporae ellipsoidales vel reniformes, $2 \cdot 5-5 \cdot 0 \times 4 \cdot 0-7 \cdot 0 \mu \mathrm{m}$. Fermentatio nulla. Glucosum, galactosum (variabile), L-sorbosum, saccharosum, maltosum, cellobiosum, trehalosum, raffinosum, melezitosum, inulin, amylum solubile, ethanolum, glycerolum, D-mannitolum, $\mathrm{D}$-glucitolum, methyl $\alpha$-D-glucosidum et acidum succinicum assimilantur at non lactosum, melibiosum, D-xylosum, Larabinosum, D-arabinosum, D-ribosum, L-rhamnosum, Dglucosaminum, methanolum, erythritolum, ribitolum (vel exigue), galactitolum, salicinum (vel exigue), acidum DLlacticum, acidum citricum, inositolum nec hexadecanum. Kalium nitricum et natrum nitrosum assimilantur at non L-lysinum, ethylaminum nec cadaverinum. Maxima temperatura crescentiae: $33-34{ }^{\circ} \mathrm{C}$. Materia amyloidea iodophila non formantur. Urea finditur. Ad crescentiam vitaminum non necessarium est. Diazonium caeruleum B positivum. Ubiquinonum majus: Q-10. Typus: $\mathrm{Y}_{4} 1^{\mathrm{T}}$, isolatus ex folio Theobroma cacao L. AS $2.2285^{\mathrm{T}}$ (= CBS $\left.9204^{\mathrm{T}}\right)$ depositus in collectione China General Microbiological Culture Collection Center, Academia Sinica, Beijing.

\section{Description of Sporobolomyces bannaensis Bai \& Zhao sp. nov.}

Sporobolomyces bannaensis (ban.na.en'sis. N.L. adj. bannaensis of Banna, referring to the geographical origin of the strains).
In malt extract, after 3 days at $20^{\circ} \mathrm{C}$, cells are ovoid, ellipsoidal to elongate, $2 \cdot 5-5 \cdot 0 \times 5 \cdot 0-10 \cdot 0 \mu \mathrm{m}$, single or in pairs (Fig. 2a). A ring, pellicle and sediment are formed. After 1 month at $20^{\circ} \mathrm{C}$, a ring, pellicle and sediment are present. On malt extract agar, after 1 month at $20^{\circ} \mathrm{C}$, the streak culture is butyrous to viscous, pink to orange-red, smooth and glistening with an entire margin. Pseudohyphae are not formed in Dalmau plate culture on corn meal agar. On corn meal agar, ballistoconidia are formed on short sterigmata and are asymmetric, ellipsoidal to reniform, $2 \cdot 5-5 \cdot 0 \times 4 \cdot 0-7 \cdot 0 \mu \mathrm{m}$ (Fig. 2b). Fermentation of glucose is negative. The following carbon compounds are assimilated:
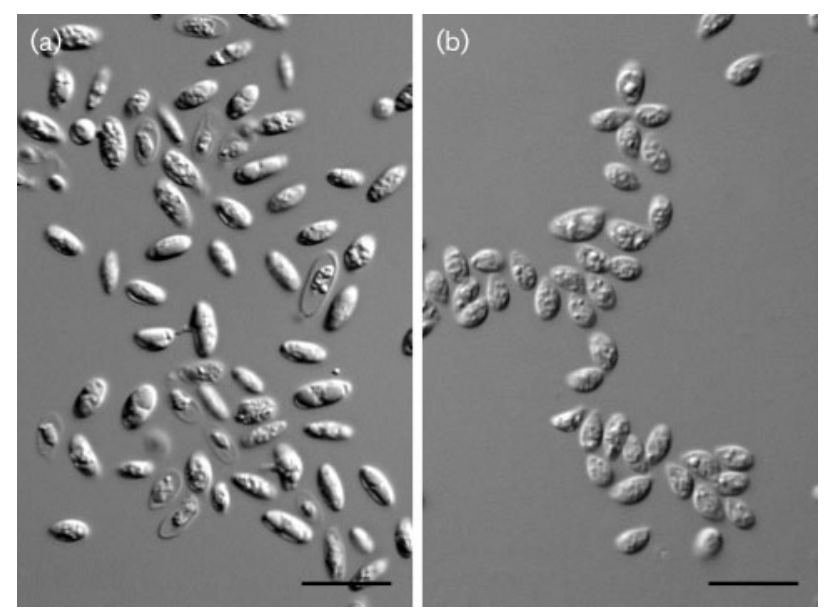

Fig. 2. Sporobolomyces bannaensis $\mathrm{Y} 41^{\top}$. (a) Vegetative cells grown in malt extract for 3 days at $20^{\circ} \mathrm{C}$. (b) Ballistoconidia produced on corn meal agar after 5 days at $20^{\circ} \mathrm{C}$. Bars, $10 \mu \mathrm{m}$. 
glucose, galactose (variable), L-sorbose, sucrose, maltose, cellobiose, trehalose, raffinose, melezitose, inulin, soluble starch, ethanol, glycerol, D-mannitol, glucitol, methyl $\alpha$-Dglucoside and succinic acid. The following are not assimilated: lactose, melibiose, D-xylose, L-arabinose, Darabinose, D-ribose, L-rhamnose, D-glucosamine, methanol, erythritol, ribitol (or weak), galactitol, salicin (or weak), DL-lactic acid, citric acid, inositol and hexadecane. $\mathrm{KNO}_{3}$ and $\mathrm{NaNO}_{2}$ are utilized as sole sources of nitrogen; L-lysine, ethylamine and cadaverine are not utilized. Growth in vitamin-free medium is positive. Maximum growth temperature is $33-34{ }^{\circ} \mathrm{C}$. Starch-like compounds are not produced. Urease activity is positive. Diazonium blue $B$ reaction is positive. The major ubiquinone is $\mathrm{Q}-10$.

The type strain, $\mathrm{Y} 41^{\mathrm{T}}$, was isolated from a wilting leaf of Theobroma cacao L. collected in Xishuang Banna, Yunnan, China in January 2001. This strain has been deposited in the China General Microbiological Culture Collection Center (CGMCC), Institute of Microbiology, Chinese Academy of Sciences, Beijing, China, as AS $2.2285^{\mathrm{T}}$ and in the Centraalbureau voor Schimmelcultures, Utrecht, The Netherlands, as CBS $9204^{\mathrm{T}}$.

\section{Acknowledgements}

This study was supported by grants no. 30170002 from the National Natural Science Foundation of China (NSFC) and KSCX2-SW-101C from the Chinese Academy of Sciences.

\section{References}

Bai, F.-Y., Takashima, M. \& Nakase, T. (2001a). Description of Bullera kunmingensis sp. nov., and clarification of the taxonomic status of Bullera sinensis and its synonyms based on molecular phylogenetic analysis. FEMS Yeast Res 1, 103-109.
Bai, F.-Y., Takashima, M., Hamamoto, M. \& Nakase, T. (2001b). Sporobolomyces yunnanensis sp. nov., a Q-10 $\left(\mathrm{H}_{2}\right)-$ containing yeast species with a close phylogenetic relationship to Erythrobasidium hasegawianum. Int J Syst Evol Microbiol 51, 231-235.

Bai, F.-Y., Takashima, M., Jia, J.-H. \& Nakase, T. (2002a). Dioszegia zsoltii sp. nov., a new ballistoconidium-forming yeast species with two varieties. J Gen Appl Microbiol 48, 17-23.

Bai, F.-Y., Zhao, J.-H., Takashima, M., Jia, J.-H., Boekhout, T. \& Nakase, T. (2002b). Reclassification of the Sporobolomyces roseus and Sporidiobolus pararoseus complexes, with the description of Sporobolomyces phaffii sp. nov. Int J Syst Evol Microbiol 52, 2309-2314.

Bai, F.-Y., Takashima, M., Zhao, J.-H., Jia, J.-H. \& Nakase, T. (2003). Bullera anomala sp. nov. and Bullera pseudovariabilis sp. nov., two new ballistoconidium-forming yeast species from Yunnan, China. Antonie van Leeuwenhoek 83, 257-263.

Boekhout, T. \& Nakase, T. (1998). Sporobolomyces Kluyver \& van Niel. In The Yeasts, a Taxonomic Study, 4th edn, pp. 828-843. Edited by C. P. Kurtzman \& J. W. Fell. Amsterdam: Elsevier.

Nakase, T. \& Takashima, M. (1993). A simple procedure for the high frequency isolation of new taxa of ballistosporous yeasts living on the surfaces of plants. RIKEN Rev 3, 33-34.

Scorzetti, G., Fell, J. W., Fonseca, A. \& Statzell-Tallman, A. (2002). Systematics of basidiomycetous yeasts: a comparison of large subunit D1/D2 and internal transcribed spacer rDNA regions. FEMS Yeast Res 2, 495-517.

Takashima, M. \& Nakase, T. (2000). Four new species of the genus Sporobolomyces isolated from leaves in Thailand. Mycoscience 41, 357-369.

Yamada, Y. \& Kondo, K. (1973). Coenzyme Q system in the classification of the yeast genera Rhodotorula and Cryptococcus and the yeast like genera Sporobolomyces and Rhodosporidium. J Gen Appl Microbiol 19, 59-77.

Yarrow, D. (1998). Methods for the isolation, maintenance and identification of yeasts. In The Yeasts, a Taxonomic Study, 4th edn, pp. 77-100. Edited by C. P. Kurtzman \& J. W. Fell. Amsterdam: Elsevier. 